\title{
A survey of coastal environments in the vicinity of Nain, Labrador
}

\author{
Robert Gilbert, Alec Aitken" and Brian Mclaughlin:* \\ Department of Geography, Queen's University, Kingston, Ont. K7L 3N6 \\ "Department of Geology, MoMaster University, Hamilton, Ont. L8S $4 M 1$ \\ *Department of Biology, Queen's University, Kingston, Ont. K7L $3 N 6$
}

\begin{abstract}
On the coast of Labrador in sheltered locations, broad intertidal flats have developed despite isostatic rebound of about 0.3 metres per hundred years. The action of sea ice is a major process controlling the distribution of boulders on the surface, which in turn determines the nature of the substratum and the biota which inhabits it. The stability of the surface, the abundance of boulders and the number and diversity of plants and animals increases from a barren zone near shore to luxuriant growths of algae (especially Fucus sp.), barnacles and molluscs (dominated by Mytilus edulis) at the boulder barricade and associated tide pools near the outer edge. A number of the burrowing molluscs (especially Macoma balthica) and polychaetes (including Arenicola marina) prefer the finer, softer sediments of the inner and middle intertidal flats.
\end{abstract}

The subtidal environment on exposed coasts and channels consists of a lag of gravel, cobbles and boulders. Encrusting, calcified algae cover the surfaces along with green and brown algae. In protected areas where sand and mud have accumulated, polychaetes dominate to about 15 to $20 \mathrm{~m}$ depth on sand, and molluscs and echinoderms are found on the finer sediments below.

On exposed, moderately and steeply sloping bedrock shores above high water, a prominent barren zone occurs. Elsewhere the sand ridges and coastal sand dunes associated with beaches are thickly colonized by grasses, especially Elymus mollis. Blowouts are common behind these areas. Salt marshes occur on shores of low slope. These are small compared to marshes to the south and are made up of turf of grasses dominated by Puccinellia phryganodes which terminates on the barren surface of the intertidal flats.

En dépit d'un relèvement isostatique d'environ 0.3 mètres par siècle, de vastes zones d'estran se sont formées dans les secteurs abrités de la côte du Labrador. L'action des glaces marines constitue l'élément majeur qui y limite la distribution des blocs en surface et, ce faisant, détermine la nature du subtrat et son benthos. A portir d'une zone littorale dénudée, la stabilité du substrat, l'abondance des blocs ainsi que le nombre et la diversite des plantes et des animaux augmentent pour enfin former les thalles riches en algues (plut spécialement Fucus sp.), anatifes et mollusques (domines par Mytilus edulis) que l'on voit sur l'encorbellement rocheux et dans les marmites. Nombre de mollusques fouisseurs (surtout Macoma balthica) et d'annélides polychètes préfêrent cependant les sédiments plus fins et plus tendres du haut et du milieu de plage.

L'environnement infracotidal des points exposés et des chenaux consiste en un fonds de blocs, cailloux et graviers qui sont couverts d'algues calcaires incrustantes et d'algues vertes ou brunes. Les sables et les vases se sont accumulés dans les secteurs abrités: là, les 15 ou $20 \mathrm{~m}$ supérieurs sont des sables à polychétes, en contrebas desquels on trouve des sédiments plus fins où vivent mollusques et échinodermes.

Là ou la plate-forme rocheuse est exposée et en pente forte ou modérée, on trouve un zone dênudée importante. Ailleurs, Elymus mollis forme d'épais herbus couvrant les crètes sableuses et les dunes côtières alliées aux plages, et derrière lesquels les décapages éoliens sont numbreux. Les plages en faible pente renferment des marais salants d'étendue moindre, cependant, que ceux plus au sud. Elles prennent la forme d'un schorre dominé par Puccinellia phrygarnodes et borné par une zone d'estran stérile.

\section{INTRODUCTION}

The physiographic classification of the coast of Labrador by Barry et al. . (1977), Woodword-Clyde (1980) and McLaren (1980) provides background for detailed studies of physical and biological processes. This paper attempts to build on that work with a preliminary, on-site investigation of the

MARITIME SEDIMENTS AND ATLANTIC: GEOLOGY 20. $143-155$ (1984)

[Traduit par le journal]

physical and the biological environments of the coasts at three sites near Nain, Labrador (Fig. 1): (l) the southeastern corner of South Aulatsivik Island and small islands to the east, (2) the large intertidal flats at the eastern end of Hillsbury Island and (3) Ford Harbour and nearby seaward islands. This work is part of the Offshore Labrador Biological Studies and details are presented by Gilbert et al. (1982). 


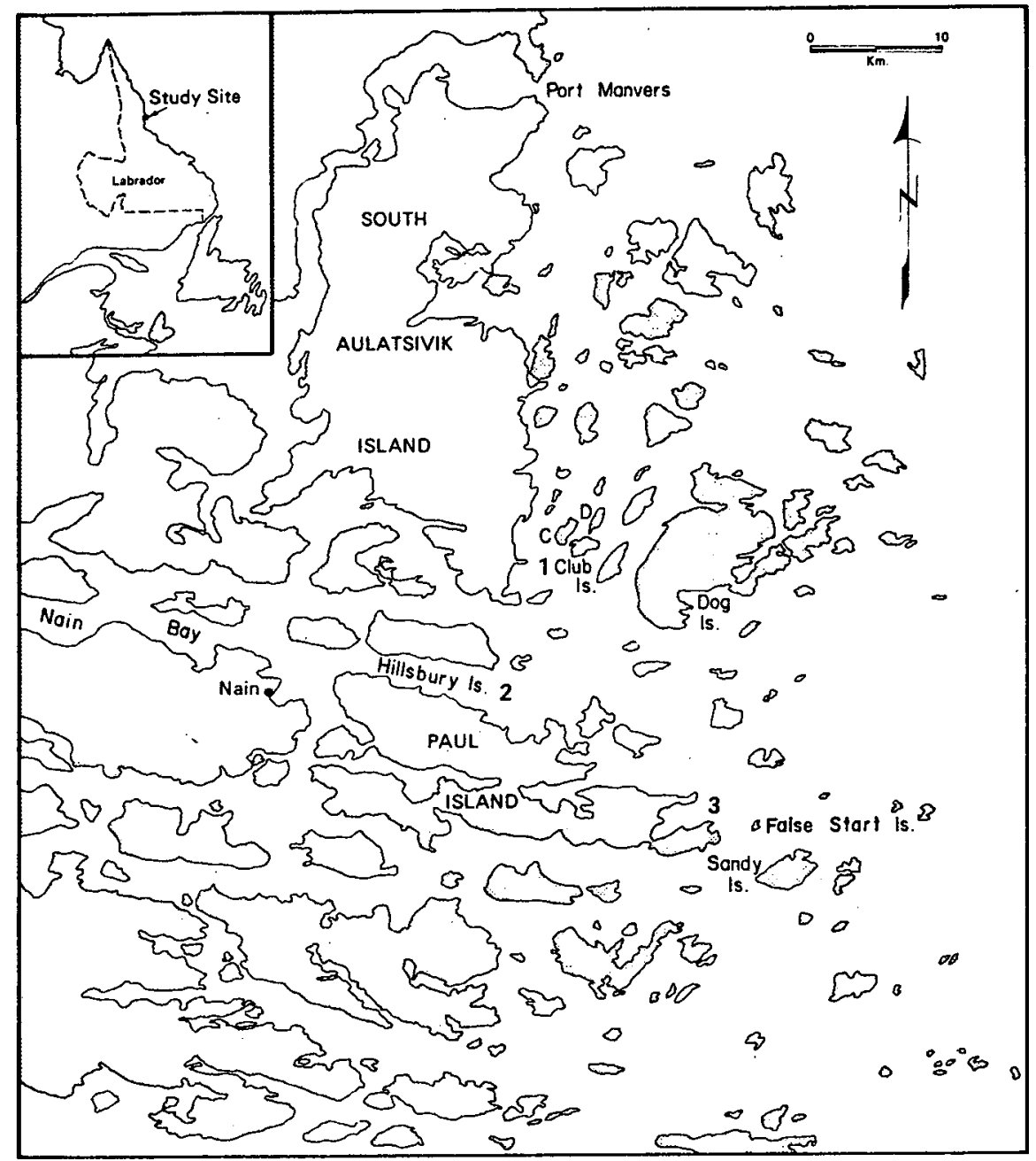

Fig. 1 - Location of study sites 1, 2 and 3 (Ford Harbour) in the Nain region and place names referred to in the text. C - Central Island, D - Dumbell Island.

\section{BACKGROUND}

Nain marks the division between the rolling hills of the George Plateau to the south and west, and the mountains of the Labrador Highlands to the north. The coast is deeply indented with fiords, bays and passages which extend $60 \mathrm{~km}$ seaward as an extensive network of islands forming a classical skerry coast. Much of the sea in the skerry zone is 50 to $100 \mathrm{~m}$ deep and the fiords are up to 180 $\mathrm{m}$ deep. There is apparently free exchange of water throughout all depths in the coastal zone with the Labrador Sea beyond (cf. Nutt 1963, Nutt and Coachman 1956).

Raised marine features are the dominant sedimentary landforms of the coast, and the patterns of coastal emergence have had a significant effect on the present coastal forms and processes. The marine limit decreases from $88 \mathrm{~m}$ at Ford Harbour (Daly 1922) to $41 \mathrm{~m}$ east of South Aulatsivik Island (Johnson 1969). Twelve raised shores in the Nain area dated by Fitzhugh (1977) are shown in Figure 2. A linear regression fitted through the data indicates an average rate of rebound of about $0.58 \mathrm{~m} / 100$ a between about 7000 a B.P. and 1000 a B.P. The present estimated rate is $0.30 \mathrm{~m} / 100$ a (Andrews 1970).

The action of sea ice is the most important process in determining sedimentary and biological processes on the Labrador coast. Skidmore (1979) presents a summary of sea ice statistics. In the Nain Bight sea ice is more extensive because 
of the protection afforded by the concave shape of the coast and the many islands. Ice appears in the bays by about November 5 with freeze-up occurring after November 20 (Woodward-Clyde 1980). The outer coast freezes two weeks later. Ice reaches a maximum thickness of about $0.9 \mathrm{~m}$ before break-up begins, normally about May 10. The bays are usually clear of ice by June 1. Water temperatures reach maximum values of about $4.7^{\circ} \mathrm{C}$ in August (Gustajtis 1979). Temperature profiles measured at sites 1 and 3 on August 8 and 15, 1981 indicate surface values of 6.5 to $7.0^{\circ} \mathrm{C}$, the result of warming in these protected nearshore environments.

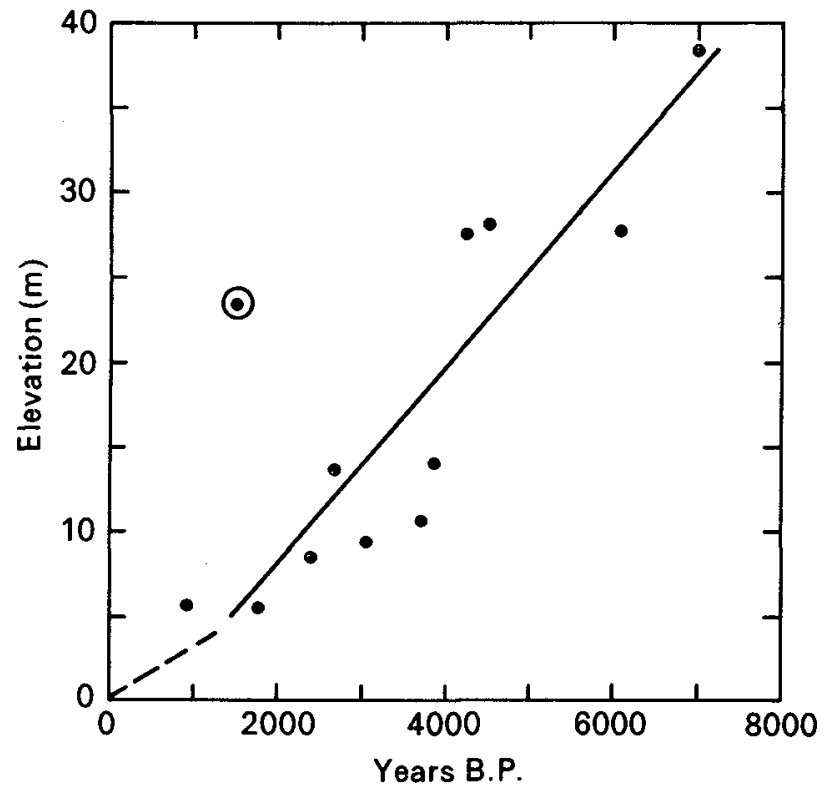

Fig. 2 - Uplift data for the Nain region from Fitzhugh (1977). Circled value is left out of the linear regression relation $E=-3.8+0.0058 \mathrm{a}$, where $E$ is the elevation in metres and $a$ is the number of years before present $\left(r^{2}=0.83,5.5<E<38\right)$. The dashed line is $0.30 \mathrm{~m} / 100$ a, the present rate according to Andrews (1970).

Tides are semidiurnal with a mean range of $1.7 \mathrm{~m}$, and spring range of 2.65 $m$. These values are intermediate between the smaller tides of southern Labrador 10.9 and $1.5 \mathrm{~m}$ at Battle Harbour) and the larger tides of northern Labrador (mean 2.5 to $3.0 \mathrm{~m}$ at Cape Chidley).

PHYSICAL ENVIRONMENT OF THE COAST
The coast of Labrador in the vicinity of Nain is made up largely of moderately to steeply sloping bedrock shores and intertidal flats. The former occur along the exposed outer coast and the sides of fiords and channels. Sediments are swept from these locations by wave action in the former case, and by the action of ice and currents in the latter.

\section{Intertidal flats}

Broad intertidal flats have developed in more sheltered locations, and form the most extensive coastal feature of the region (McLaren 1980). The origin of arctic and subarctic intertidal flats has been discussed by Rosen (1979), Lauriol and Gray (1980), Gilbert and Aitken (1981) and McCann et al. (1981) in relation to changing sea level and especially to the action of sea ice. At some locations at Nain, the width of the intertidal flats exceeds $1 \mathrm{~km}$ (Fig. 3), and they represent a major discontinuity of the shoreline. They are best developed in protected bays and other regions of shallow water (for example, between islands at site 2, Figure $3 \mathrm{~b})$, where fine sediments have accumulated.

Boulders are strewn on the surface of the intertidal flats. Most are 1 to $2 \mathrm{~m}$ diameter and are balanced on the surface of the finer sediment beneath where they have been deposited by ice action (cf. Rosen 1979, Gilbert and Aitken 1981). Except for the prominent barricades in the outer regions of the flats, the boulders are scattered randomly on the surface, although with increasing density away from shore. In many sites (see for example, Figure 3a) there are two equally well-developed boulder barricades, the outer from 10 to $50 \mathrm{~m}$ seaward and 0.5 to $\mathrm{l} \mathrm{m}$ below the inner. We speculate that the inner barricade marks a former edge of the flats where sea ice grounded (cf. Rosen 1979) while the outer barricade has formed more recently as relative sea level fell and the flats built outward. Even on some bedrock shores where intertidal flats are absent or poorly developed, as at Ford Harbour, a fringing barrier of boulders may be found 20 to $40 \mathrm{~m}$ offshore. 

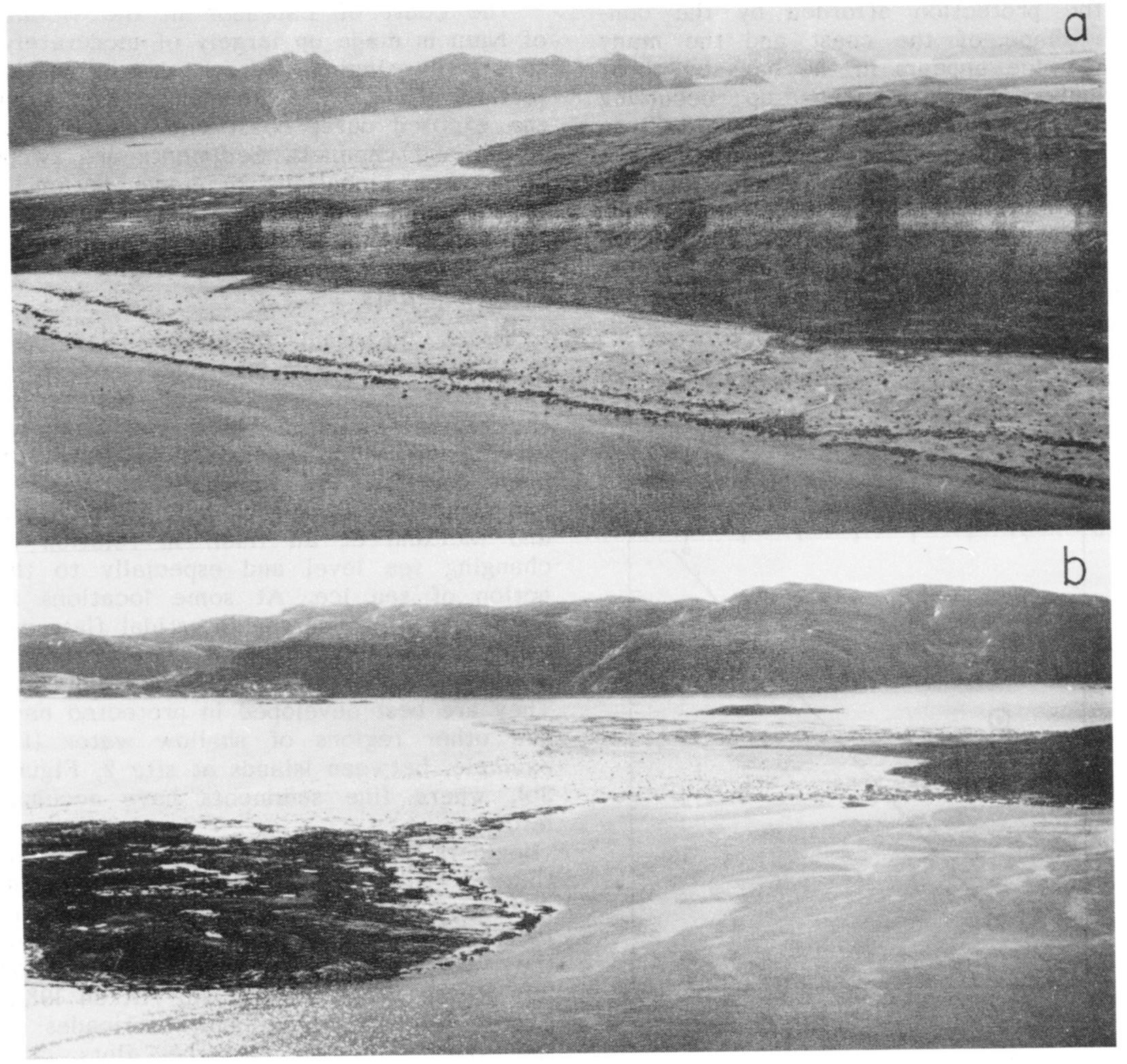

Fig. 3 - Views from the air looking over the intertidal flats (a) at site 1, and (b) at site 2. Photos by P. McLaren, Geological Survey of Canada.

At the southwest tip of the spit on False Start Island is a small area about $50 \times 50 \mathrm{~m}$ of cobble and boulder pavement (Fig. 5) distinct from the perched boulders of the intertidal flats elsewhere in the area. The stones are all about the same diameter $(0.2-0.3 \mathrm{~m})$, are closely packed, and, most remarkably, form a nearly level pavement. These features have been described in ice-bound rivers including the MacKenzie (Mackay and Mackay 1977) and the St. Lawrence (Dionne 1981), and in several coastal areas including James Bay (Martini 1981), Spitzbergen (Jahn 1977) and the sub-Antarctic (Hansom 1983). In all cases their origin is ascribed to the action of ice carried in flowing water. Shear stresses are great enough to force the stones into the mud, where they form an armour protecting the surface, and to abrade the surfaces of the stones in a manner similar to the action of a glacier (Mackay and Mackay 1977). The diameters of the stones in the feature on False Start Island are comparable to the values of 14 to $33 \mathrm{~cm}$ re- 


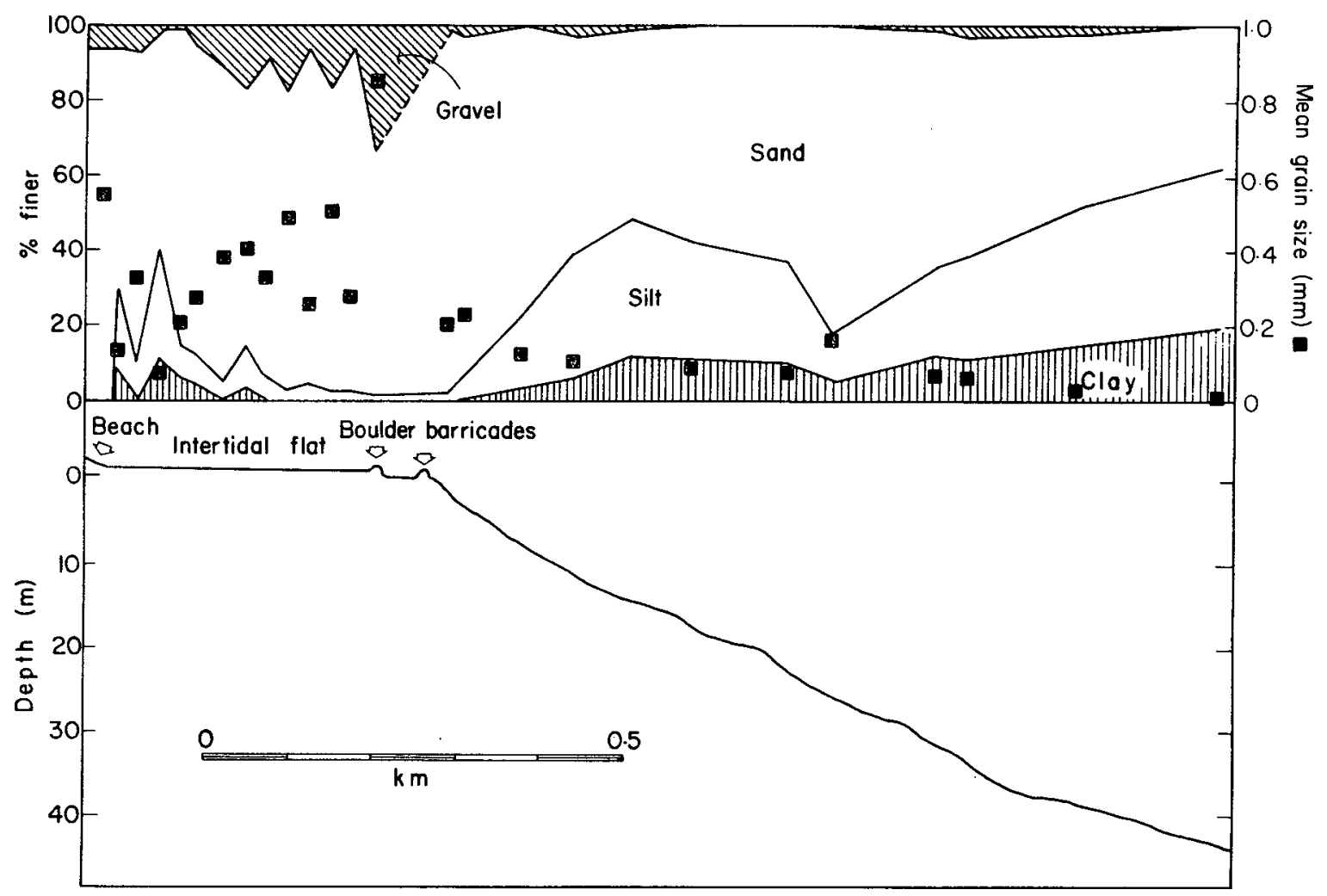

Fig. 4 - Grain-size analysis of sediment at site $\mathrm{l}$ and profile interpreted from echo soundings showing the boulder barricades.

ported by Mackay and Mackay (1977, Table 1). It is probable that these stones are more easily implanted in the mud of the intertidal flats than the larger stones which are frozen into, and carried off by, the passing ice. We have not seen similar boulder pavements elsewhere on intertidal flats in the Nain region or on Baffin Island. However, Jahn (1977) describes them as "a typical occurrence commonly observed in the polar zone" (p. 21).

It is probable that the intertidal flats at this location are subject to a significant shear stress from passing pack ice throughout a longer period in winter than in the more protected regions inshore where shorefast ice forms early in the winter. This pack ice moving past the end of False Start Island is able to form the armoured surface and to sweep the larger boulders aside in the absence of a well-developed boulder barricade (Fig. 5). Elsewhere, where the shorefast ice protects the intertidal flats, the boulders are lifted to the surface and moved by the processes more typical of eastern arctic and subarctic intertidal flats described by Rosen (1979) and Gilbert and Aitken (1981).

The beach and backshore

Three factors contribute to a widespread distribution of beaches on this portion of the coast of Labrador:

l. the moderate relief of the shore, especially as compared with the mountainous coast to the north,

2. the protection provided by the many islands and bays of this drowned skerry coast, and

3. a source of reworked glacial sediment related to isostatic rebound and erosion of higher raised beaches. Intertidal flats are also best developed where these conditions prevail, and are most frequently associated with beaches. However, in comparison to the beaches of southern Atlantic Canada (for example, Owens 1977), the active portions of these Labrador beaches are small, seldom exceeding $20 \mathrm{~m}$ wide and 1 to $2 \mathrm{~m}$ in verti- 


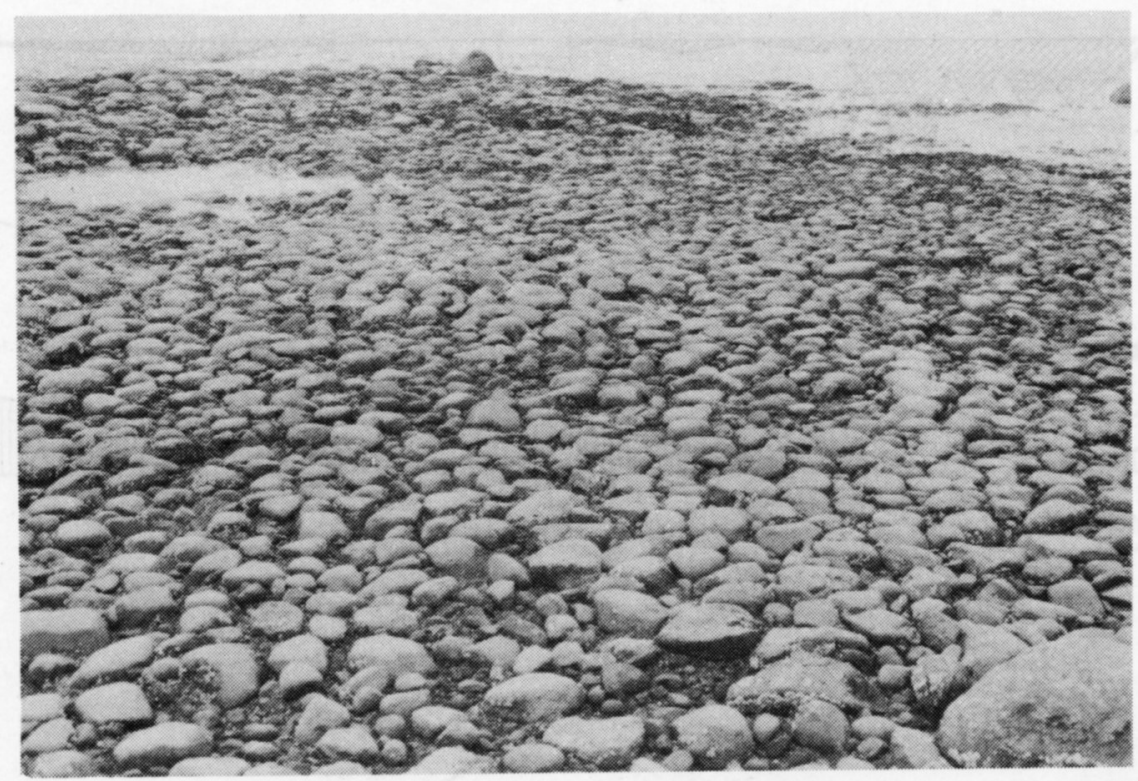

Fig. 5 - Cobble pavement at the southwest tip of False Start Island. Field of view is $3 \mathrm{~m}$ in the foreground.

cal extent. This is related to the small effective fetch associated with individual beaches and the limited distances over which longshore transport can occur (Fig. 1).

The base of the beach is marked by a sharp break in slope from the nearly flat-lying intertidal flats, and by a clear change in sediment texture from the poorly sorted, muddy gravelly sand of the flats to well sorted beach sands and gravels (Fig. 4). Normally, the gravel forms a veneer in a bank across the lower section of the beach (cf. McLaren 1980, Figure 28).

The base of the beach and top of the intertidal flats are active environments. While the fine sediments of most of the

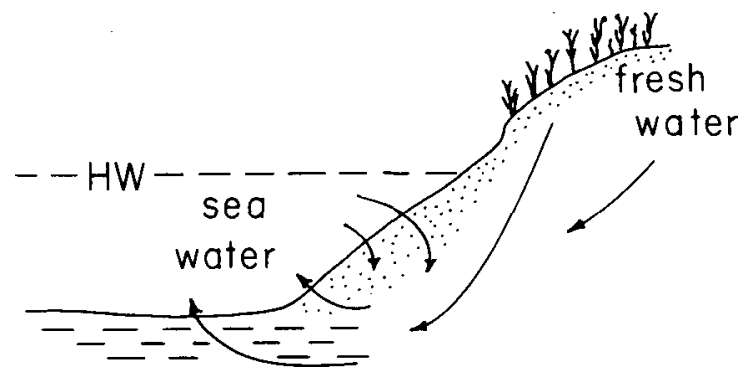

Fig. 6 - Schematic diagram of proposed fresh and salt water movements in the beach and proximal intertidal sediments below high water (HW) to produce a zone of liquifaction in the latter. Flow occurs into sediment at high tide, out at low tide. intertidal zone exhibit considerable shear strength (except where a veneer of flocculated, fine sediment less than $1 \mathrm{~cm}$ thick occurs), a zone 5 to $10 \mathrm{~m}$ wide immediately below the beach is significantly underconsolidated and easily liquified.

Three factors contributed to this condition. The first is the relatively fine grain-size of the sediments in this region. Mud (silt and clay size) content ranges from about 20 to $40 \%$ and mean grain size from 0.1 to $0.3 \mathrm{~mm}$ as compared to the mid- and outer intertidal zone with less than $10 \%$ mud and mean grain size 0.3 to $0.5 \mathrm{~mm}$ (Fig. 4). The second is the passage of sea water and fresh water from the beach into these sediments at high tide and up to the surface under the hydraulic head created by the beach at low tide (Fig. 6). As well, the fresh water may be forced upward by the more dense sea water which saturates the intertidal flats. Water rising through these sediments may be able to liquify them partially (cf. Terzaghi 1956).

The third relates to freezing and ice action. This water-saturated area is the most distrubed by freeze/thaw processes associated with ice formation and is least protected by boulders from sea ice under the influence of tides (Gilbert and Aitken 1981). 


\section{BIOLOGICAL ENVIRONMENT OF THE COAST}

Intertidal biota

The distribution of biota in the intertidal area is controlled by several physical conditions (Ellis and Wilce 1961, Stephenson and Stephenson 1972, Lee 1973):

i) the availability of suitable substrates for colonization,

ii) seasonal variations in surface water salinity,

iii) the degree of exposure to waves, and

iv) the abrasion by sea ice.

On the broad intertidal flats, the substrate chiefly controls the distribution of biota, so that the surface may be conveniently divided into the inner zone of partially liquified muds, a middle zone of more stable muddy sands, and an outer zone of sands and gravels which includes the boulder barricades. The distribution of the most abundant organisms described below is summarized in Figure 7 .

The inner flats are largely devoid of biota, although the gastropods Littorina saxatilis and L. obtusata were collected from the sediment surface in this area. Littorina abundance declines away from shore except at site 3 where they are found in great numbers in the outer region.

Algal species which occur on the inner flats include Ralfsia clavata, Enteromorpha intestinalis, and $E$. prolifera. Ralfsia encrusts rock surfaces at the high water mark on bedrock outcrops. Enteromorpha sp. grow attached to pebbles at the high water mark on gravel beaches. Both species of Entermorpha are associated with freshwater seeps on these beaches.

Barnacles (Semibalanus balanoides) colonize the base of boulders from the midintertidal zone to the low water mark, increasing in abundance seaward through this zone. Similarly, the phaeophycean algae, Chordaria flagelliformis and Dictyosiphon foeniculaceus, grow on pebbles in shallow tidal pools in the mid-intertidal zone. These pools are inhabited by a variety of free-swimming amphipods, including Gammarus oceanicus, G. setosus, G. lawrencianus, Onisimus litoralis and Orchomene pinguis. Macoma balthica inhibits the muddy portions of this zone.

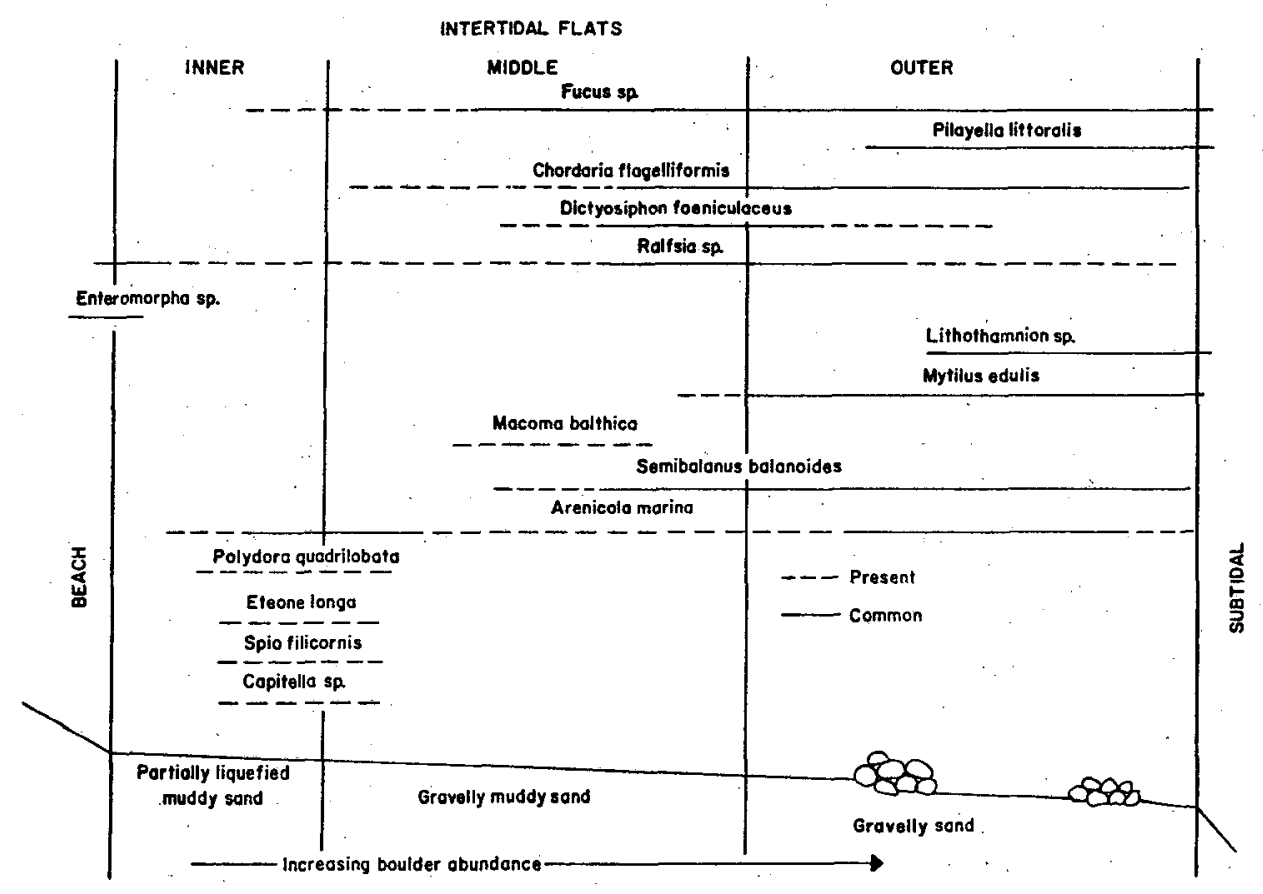

Fig. 7 - Generalized model of the sedimentary and biological environments on intertidal flats in the vicinity of Nain. 
The transition from muddy sands to gravelly sands on the outer part of the intertidal flats is accompanied by an increase in the stability of the sediments. Chordaria flagelliformis, living attached to the pebble substrate, forms dense stands between the mid- and outer intertidal zone, and extends into the upper subtidal environment. Toward the low water mark, Fucus vesiculosis competes with Fucus edentatus for space on boulders. Both these algae grow on cobbles and boulders in the shallow subtidal environment. These algae, along with the barnacles and the mollusc, Mytilus edulis, form a cover that approaches $100 \%$ along the protected sides of the boulders, ? especially near the boulder barricade. Large specimens of Chorda tomentosa are attached to pebbles in this area. Lithothamnion glaciale also encrusts pebble surfaces in the outer intertidal zone. Pilayella littoralis, growing epiphytically on Fucus sp. at the outer boulder barricade, also extends into shallow water below the low tide mark. Desmerestia aculeata was collected in shallow water living attached to pebbles. Kelps (Laminaria sp.) form a dense vegetative cover in the upper subtidal zone.

The arenicolid polychaete, Arenicola marina, burrows in gravelly sand between the inner and outer barricade, although at site 2 Arenicola is distributed more widely across the intertidal flats, with juvenile specimens first appearing $60 \mathrm{~m}$ from the beach. Their characteristic feeding cones indicate a rapid reworking and aeration of surficial sediments. At sites 1 and 2 Arenicola abundance is 2-4 m-2 where they occur, whereas in the back of Ford Harbour (site 3) densities in excess of $11 \mathrm{~m}-2$ were recorded. Associated with Arenicola at some sites are the polychaetes Polydora quadrilobata, Etone longa, Nephtys caeca, Spio filicornis, Capitella sp., Chaetozone setosa and Phyllodoce maculata, although these were observed to inhabit a less sandy substratum than the Arenicola.

The biota and their zonation on Sandy and False Start Islands (Fig. 1) is somewhat different because of the greater exposure of these coasts. The gastropods, polychaetes and several macroalgae collected in the inner intertidal zone at sites 1 and 2, and in Ford Harbour are absent. The sediments of the inner intertidal zone consist of partially liquified sandy silts and are essentially barren. In the mid- and outer intertidal zone the sediments change to sandy gravels and gravelly sands. Mytilus edulis and Arenicola marina inhabit the lower intertidal zone. Mytilus lives attached to pebbles on the sediment surface, while Arenicola burrows in the coarse sediment. A single boulder barricade delimits the outer edge of the intertidal flats. The boulders support a moderate cover of fucoid algae and barnacles. Small kelps (Laminaria sp. and Alaria sp.) were observed on boulder and cobble surfaces at the low water level. A turf of smaller algae including Sphacelaria plumosa, Antithamnion pylaisaei and Ceramium rubrum live attached to the holdfasts of the kelps.

\section{Subtidal biota}

Our understanding of the subtidal environment is based on 32 Ekman grab samples to a maximum depth of $50 \mathrm{~m}$ at sites 1 and 3 . It is apparent that this environment is sufficiently diverse that more samples are required to document completely the species present.

At site 1 sediments in the subtidal environments grade from gravelly sands in the vicinity of the boulder barricade through muddy sands to sandy mud at 45 $m$ depth (Fig. 4) reflecting the decreasing energy with depth.

Six invertebrate phyla: Mollusca, Annelida, Arthropoda, Cirripedia, Echinodermata and Formanifera are represented in the collections from this site. Two biological assemblages may be defined qualitatively:

l) a polychaete assemblage associated with slightly gravelly sands and muddy sands between 0 and $15 \mathrm{~m}$ depth. Nephtys ciliata, Pectinaria granulata and Spio filicornis are abundant at these depths.

2. a mollusc-echinoderm assemblage associated with muddy sand and sandy mud at 15 to $45 \mathrm{~m}$ depth. The molluscs, Nucula tenuis and Macoma balthica, the 
polychaete, Nephtys ciliata, and the holothurians, Chirodota laevis and Cucumaria calcigera, are abundant at these depths.

The channels between Central, Club and Dumbell Islands at site $I$ have a substrate of small cobbles and pebbles which are largely overgrown by encrusting calcified algae. The absence of particles smaller than about $1 \mathrm{~cm}$ and the varied biota present indicate the activity of strong currents in these passages and thus the rapid exchange of water. Algal species collected on cobbles include Kvaleya epilaeve, Leptophytum laeve, L. foecundum, Clathomorphum circumscriptum, C. compactum, Lithothamnion glaciale, Hildenbrandia rubra, Pteroderma maculiforme and Pseudolithoderma sp. The epifauna associated with the cobble substrate includes the bivalves, Thaysira gouldi and Astarte sp., the gastropods, Tachyrhynchus reticulatus and Trichotropis borealis, and the chitons, Ischnochiton albus and Tonicella marmorea. Crabs, Hyas areneus, and sea urchins, Strongylocentrotus droebachiensis were also collected at these sites.

In shallow water, the substrate is composed of muddy sands and supports a variety of molluscs and polychaetes. A sample from $29 \mathrm{~m}$ of water contained juvenile specimens of molluscs, Mya truncata, Hiatella arctica and Macoma bal- thica, as well as Astarte sp. and Clinocardium ciliatum. In $17 \mathrm{~m}$ of water polychaetes dominate the benthic fauna and members of the families Sabellidae, Spionidae, Maldanidae and Flabelligeridae are well represented.

At site 3 (Ford Harbour) sediments in the subtidal environment grade from gravelly sands in the vicinity of the boulder barricade through muddy sands to sandy mud at $46 \mathrm{~m}$ depth. Mean grain size decreases from $0.2 \mathrm{~mm}$ in the shallow water to near $0.01 \mathrm{~mm}$ at depth. Five invertebrate phyla: Mollusca, Annelida, Arthropoda, Cirripedia, and Echinodermata are represented in the collections from this site. Sediments at depth are somewhat finer than those recovered from the less enclosed bay at site l. Two biological assemblages may be defined qualitatively:

1) a mollusc-polychaete assemblage associated with gravelly sands and muddy sands at 0 to $12 \mathrm{~m}$ depth. Macoma balthica and Pectinaria granulata are abundant at these depths.

2) a mollusc-polychaete assemblage associated with muddy sand and sandy mud at 12 to $46 \mathrm{~m}$. The molluscs, Macoma balthica and Yoldia hyperborea, and the polychaetes, Pectinaria granulata and Nephtys ciliata, are abundant at these depths.

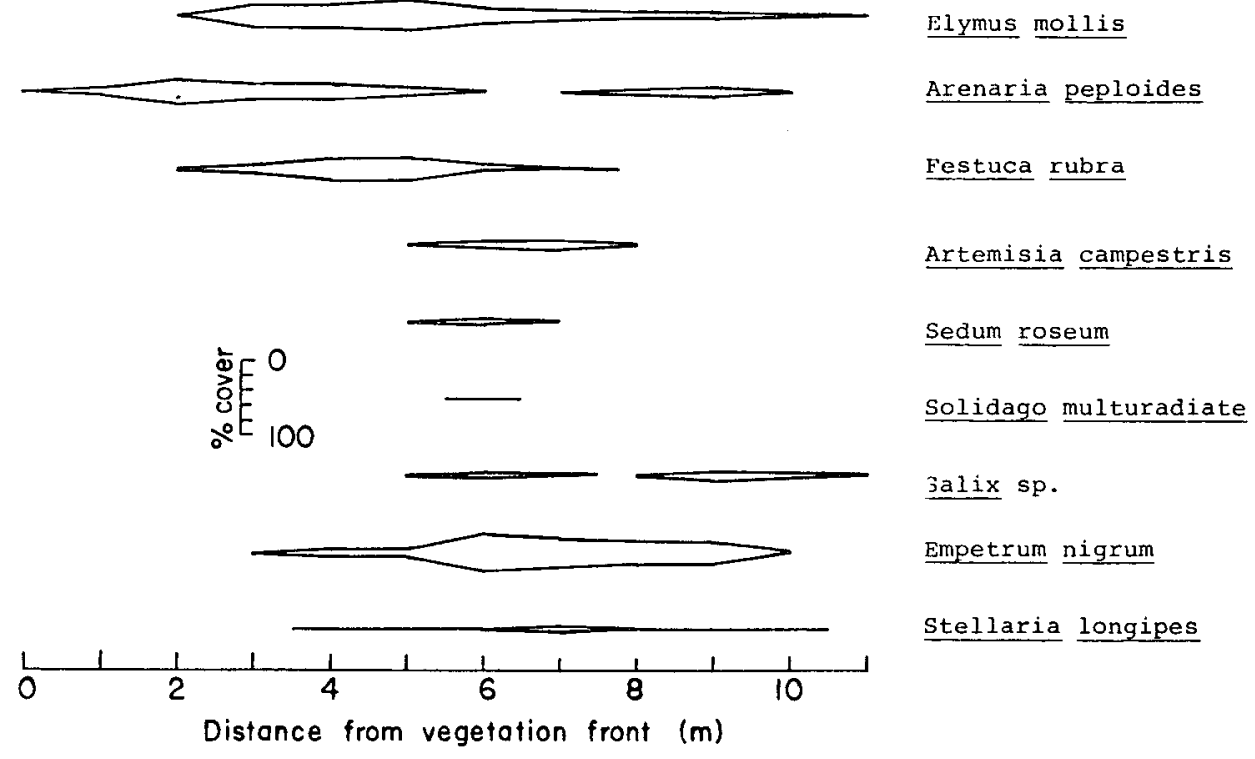

Fig. 8 - Distribution and cover of vegetation in the sand ridge community behind the beach on the north side of site 3 (Ford Harbour). See also Figure 9. Data are from $50 \times 50 \mathrm{~cm}$ quadrats at $1 \mathrm{~m}$ intervals. 


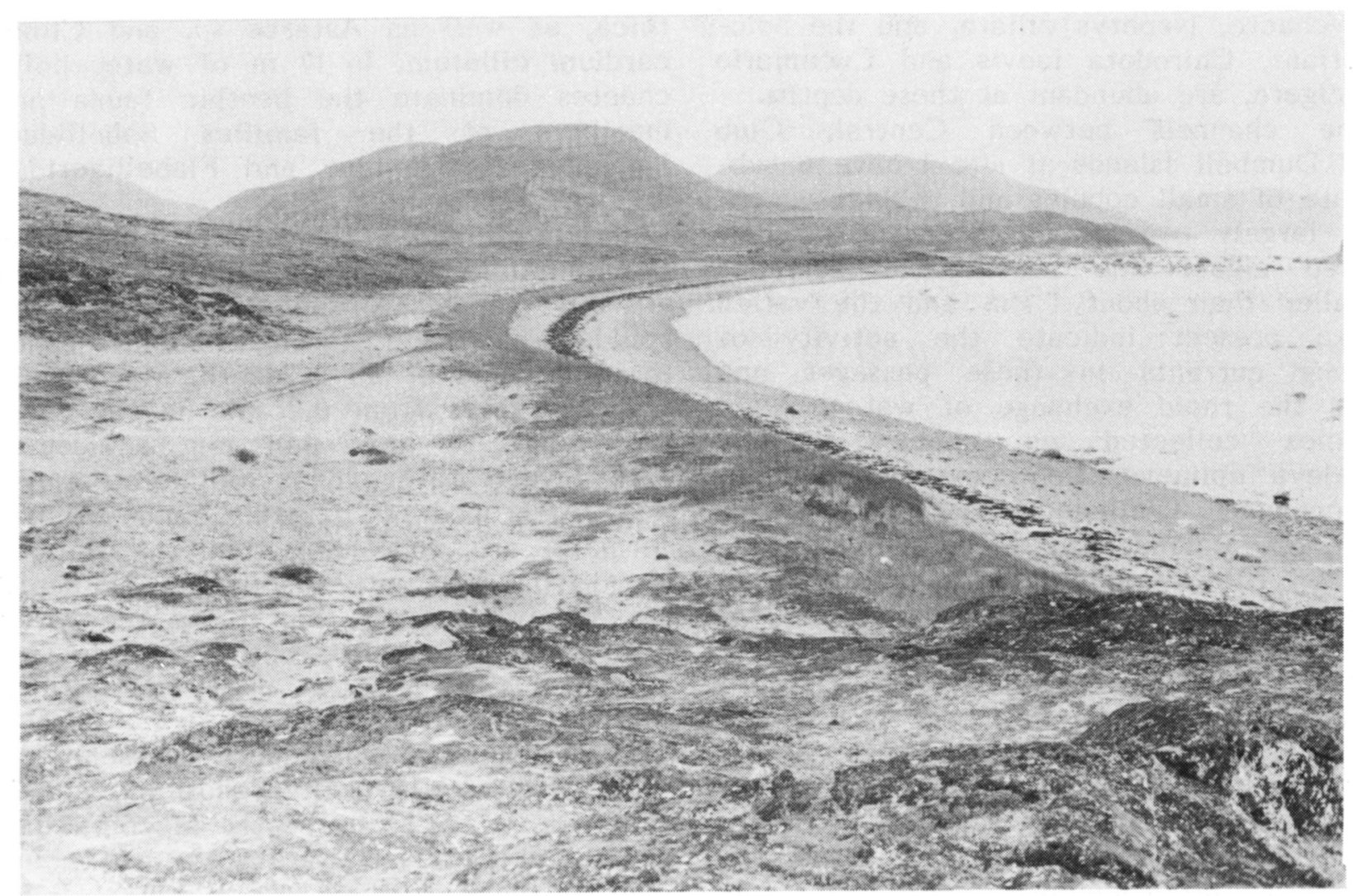

Fig. 9 - View along the beach on the north side of site 3 (Ford Harbour) showing coastal dune stabilized by Elymus mollis and the extensive blowout behind.

Supratidal biota

The region from the average high tide level to the maximum extent of the influence of sea water and sea ice comprises three biologic communities: the barren zone, the beach community and the salt marsh community. The barren zone occurs on exposed, moderately and steeply sloping bedrock shores. It is fringed above by a zone of terrestrial vegetation, especially crustose lichens, and below by a zone of perennial bluegreen and filamentous green algae below the mid-tide level.

Where beaches occur, the faces are barren of living biota, but the sand ridges and coastal sand dunes which back the beaches are thickly colonized. Figure 8 summarizes the distribution of plants on a beach at site 3 shown in Figure 9, and is typical of beaches in the area. Vegetation is dominated by the sea lyme grass, Elymus mollis, with an understory of Festuca rubra. At this site, crowberry, Empetrum nigrum is also a major component of the dense understory. Similar sand ridge communities dominated by Elymus were described from northern Labrador by Polunin (1948) and the Hudson Bay Lowlands by Heagy and Cook (1979) and Glooschenko (1978). In more exposed sites the sagewort, Arenaria peploides is a major component of the Elymus community. The dense clumps which it forms are important in stabilizing the beach sands. It is found both in front of the sand ridge toward the beach face and behind in the blown-out areas. It was most extensive on the exposed gravel beaches at False Start and Sandy Islands. In addition to the plants shown in Figure 8, arrow-grasses Triglochin palustre, grasses, Agrostis borealis, Duptonia fisheri, Poa eminens and P. labradorica, sedges Carex bigelowii, C. mackenziei, C. maritima and C. subspathacea, and herbs Koenigia islandica, Potentilla egedii, Astragulus sp., Ligusticum scothiegedii, Astragulus sp., Ligusticum scothicum and Mertensia maritima also occur in lesser quantites. 
The third supratidal environment is that of the salt marsh which is restricted to shorelines of low slope (less than $2^{\circ}$ ) where beaches are frequently poorly developed or absent and which are protected from wave action. In the Nain area the salt marsh is above all but the highest spring tides and storm events, and is infrequently inundated. As well, the distinction between an upper and lower marsh on the basis of differences in vegetation and physical environments as occurs elsewhere (Chapman 1960) does not apply here. The salt marsh terminates on the barren intertidal flat at about the lower high water mark in a turf dominated by the grass Puccinellia phryganodes (Fig. 10) which is frequently eroded into isolated clumps along the outer edge. The muds of the intertidal flat are washed into this turf more frequently than overwash of the sandridge community occurs, and are trapped by the grass to form a resistant mat with roots of the vegetation. Red fescue, Festuca rubra, is found within some salt marshes, but does better within the coastal dune community. This may be due to its limited capacity on water logged soils compared to Puccinellia phryganodes (Piggott 1974). Other species present include the sedges, Carex subspathacea, C. mackenziei, the cinquefoil, Potentilla egedii and the arrow-grass Triglochin palustre. The alkali-grass, Puccinellia phryganodes, often in association with the sedge, Carex subspathacea was found in northern Labrador salt marshes (Polunin 1948), other parts of the Canadian Arctic (Kershaw 1976, Glooschenko 1978, Heagy and Cook 1979) and in arctic salt marshes of other parts of the world (Chapman 1960). Studies of vegetation in Russian arctic salt marshes again found Puccinellia phyrganodes to dominate the communities, with the chickweed, Stellaria humifusa, present in some cases (Walter 1977) as at Nain. In the arctic group of salt marshes diversity of species is limited, and succession is very simple and of ten somewhat fragmented, due to environmental constraints (Chapman 1977).

In a few isolated locations in the Nain region the salt marshes may exceed 100 $m$ wide, although they are more commonly a few metres to a few tens of metres wide and occur in isolated pockets. Along the coasts of northern Labrador, Polunin (1948) similarly found that the salt marshes were diminutive, the best developed occurring on shores of sheltered brackish lagoons. In general, the Labrador salt marshes are less than $200 \mathrm{~m}$ wide (McLaren 1980) compared to the extensive salt marshes of the James Bay lowland of several kilometres width (Gloos-

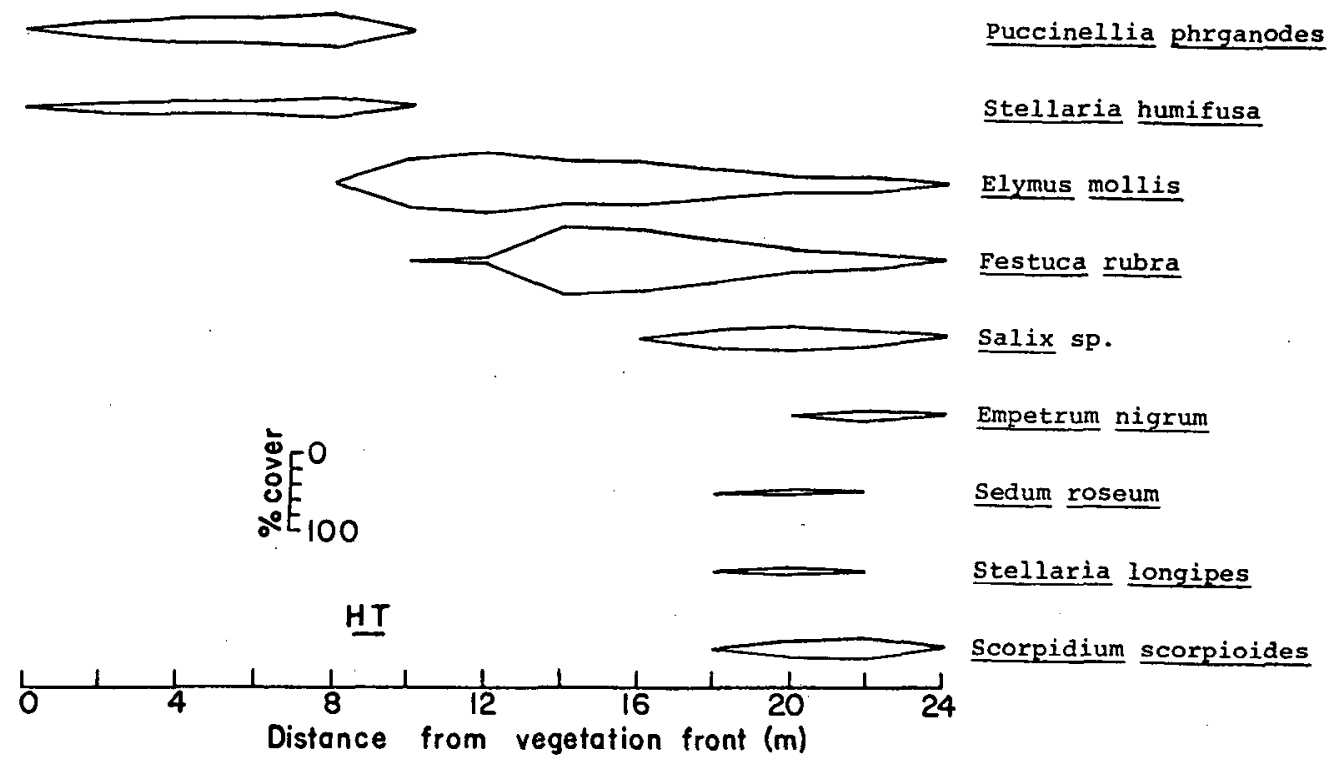

Fig. 10 - Distribution and cover of plants in the salt marsh community (extending from 0 to $10 \mathrm{~m}$ from the vegetation front) and sand ridge community behind at the southwest of site 3 (Ford Harbour). 
chenko 1978). In Labrador the more steeply rising backshore is a major factor controlling the extent of salt marsh development.

Although innudation is restricted to infrequent events, sea ice is pushed into the salt marsh from time to time as evidenced by small piles and lines of cobbles and boulders. Although there is some minor scouring of the surface and perhaps erosion of small hollows, the vegetation is sufficiently robust to survive this stress. The back of the salt marshes are marked by lines of flotsam, especially Fucus debris, and by a gradual change to terrestrial tundra vegetation. However, the effect of the sea water in this region is relatively short lived. On 11 August 1981 at site 1 the salinity of the soil water in the salt marsh varied from 0.02 to $0.20 \%$ between 45 and $62 \mathrm{~m}$ back from the edge of the intertidal flats.

\section{CONCLUSIONS}

In this preliminary study we have shown that the coastal environment of central Labrador is characterized by landforms which are responding to changing sea level and especially the action of sea ice. The intertidal and subtidal areas are especially rich in biota. However, we understand very little of their ecology, their adaptations to stress, especially created by ice, and their role in the food chain to the larger animals of the region. Even the list of these organisms is incomplete. Careful studies of the physical and biological proceses of the coast are the essential next step in understanding this environment.

\section{ACKNOWLEDGEMENTS}

The study was funded by Petro-Canada Exploration Inc. We appreciate verification of marine faunal specimens by $D$. Laubitz, J. Fournier, M.F.I. Smith and P. Frank of the National Museum of Canada; marine flora by $R$. Hooper of Memorial University, and C. Bird of the Atlantic Regional Labratory; and terrestrial flora by J. McNeill, S. Aiken, S.I. Warwick, and P.M. Catling of Research Branch,
Biosystematics Research Institute, Agriculture Canada. We thank J.-C. Dionne, P. McLaren, P.S. Rosen and J.-M. Sempels for their helpful comments on the paper.

ANDREWS, J.T. 1970. Present and postglacial rates of uplift for glaciated northern and eastern North America derived from posiglacial uplift curves. Canadian Journal of Earth Sciences, 7, pp. 703-715.

BARRY, R.G., CRANE, R.G., LOCKE, C.W., LOCKE, W.W., and MILLER, G.H. 1977. The Coastal Environment of Southern Baffin Island and Northern LabradorUngava. Report for Imperial Oil Ltd., Aquitaine Co. of Canada Ltd., and Canada Cities Service Ltd., Arctic Petroleum Operators Association, Project 138, 166p.

CHAPMAN, V.J. 1960. Salt marshes and salt deserts of the world. Leonard Hill (Books) Limited, London, 392p.

CHAPMAN, V.J. 1977. Introduction. In Ecosystems of the world: Volume 1, Wet coastal ecosystems. Edited by V.J. Chapman. Elsevier Scientific Publishing Company, New York, pp. 1-29.

DALY, R.A. 1922. The geology and scenery of the northeast coast. In Labrador. The Country and the People. Edited by W.T. Grenfell. pp. 81-139.

DIONNE, J.C. 1981. Le deplacement de mega-blocs par les glaces sur les rivages du Saint-Laurent. National Research Council of Canada, Associate Committee for Research on Shoreline Erosion and Sedimentation. Workshop on Ice Action on Shores, pp. 53-80.

ELLIS, D.V., and WILCE, R.T. 1961. Arctic and Subarctic examples of intertidal zonation. Arctic, 14, pp. 224-$\because 235$.

FITZHUGH, W. 1977. Population movement and culture change on the central Labrador coast. Annals of the New York Academy of Sciences, 288, pp. 481-497.

GILBERT, R, and AITKEN, A.E. 1981. The role of sea ice in biophysical processes on intertidal flats at Pangnirtung (Baffin Island), N.W.T. National Research Council of Canada Associate Committee on Shoreline Erosion and Sedimentation. Workshop on Ice Action on Shores, pp. 89-103.

GLOOSCHENKO, W.A. 1978. Above-ground biomass of vascular plants in a subarctic James Bay salt marsh. Canadian Field-Naturalist, 92, pp. 30-37.

GUSTAJTIS, K.A. 1979. Oceanography and climatology of the Labrador Sea. Chapter 4 In Oil spill scenario for the Labrador Sea. Edited by B.R. LeDrew and K.A. Gustajtis. Environmental Protection Service, Ottawa, Economic and Technical Review Report, EPS 3-EC79-4, pp. 79-148.

HANSOM, J.D. 1983. Ice-formed intertidal bounder pavements in the sub-Antarctic. Journal of Sedimentary Petrology, 53, pp. 135-145.

HEAGY, M.I. and COOKE, F. 1979. Vegetation characteristics of Snow Geese nest sites. Canadian Journal of Botany, 57, pp. 1502-1504.

JAHN, A. 1977. Periglacial forms produced by shore ice at Hornsund (Spitsbergen). Acta Universitatis Wratislaviensis, 387, pp. 19-29.

JOHNSON, J.P. 1969. Deglaciation of the central NainOkak Bay Section of Labrador. Arctic, 22, pp. 373-394.

KERSHAW, K.A. 1976. The vegetational zonation of the East Pen Island salt marshes, Hudson Bay. Canadian Journal of Botany, 54, pp. 5-13.

LAURIOL, B., and GRAY, J.T. 1980. Processes responsible for the concentration of boulders in the intertidal zone in Leaf Basin, Ungava. Geological Survey 
of Canada, Paper 80-10, pp. 281-292.

LEE, R.K.S. 1973. General ecology of the Canadian Arctic benthic marine algae. Arctic, 26, pp. 32-43.

MACKAY, J.R., and MACKAY, D.K. 1977. The stability of ice-push features, Mackenzie River, Canada. Canadian Journal of Earth Sciences, 14, pp. 2213-2225.

MARTINI, I.P. 1981. Ice effect on erosion and sedimentation on the Ontario shores of James Bay, Canada. Zeitschrift fur Geomorphologie, Neue Folge Band 25, pp. 1-16.

MCCANN, S.B., DALE, J.E., and HALE, P.B. 1981. Ice conditions and effects in a macrotidal subarctic environment, southeast Baffin Island. National Research Council of Canada Associate Committee on Shoreline Erosion and Sedimentation. Workshop on lce Action on Shores, pp. 105-115.

MCLAREN, P. 1980. The coastal morphology and sedimentology of Labrador: A study of shoreline sensitivity to a potential oil spill. Geological Survey of Canada Paper 79-28, 4lp and 2 maps.

NUTT, D.C. 1963. Fjords and marine basins of Labrador. Polar Notes, 5, pp. 9-24.

NUTT, D.C., and COACHMAN, L.K. 1956. The oceanography of Hebron Fjord, Labrador. Journal of the Fisheries Research Board of Canada, 13, pp. 709-758.

OWENS, E.H. 1977. Coastal environments of Canada: the impact and cleanup of oil spills. Environmental Protection Service, Environment Canada, Economic and Technical Review Report, EPS 3-EC-77-13, 413p.

PIGGOTT, C.D. 1974. Influence of mineral nutrition on the zonation of flowering plants in coastal salt marshes. In Ecological aspects of the mineral nutrition of plants. Edited by I.H. Rorison. Blackwell Scientific Publications Ltd., Oxford, pp. 25-35.

POLUNIN, N. 1948. Botany of the Canadian Eastern Arctic. Part 3, Vegetation and Ecology. National Museum of Canada Bulletin No. 104, 304p.

ROSEN, P.S. 1979. Boulder barricades in central Labrador. Journal of Sedimentary Petrology, 49, pp. 1113-1124.

SKIDMORE, J.M. 1979. Labrador Sea synoptic ice description. Chapter 5. In Oil spill scenario for the Labrador Sea. Edited by B.R. LeDrew and K.A. Gustajtis. Environmental Protection Service, Ottawa, Economic and Technical Review Report, EPS 3-EC-79-4, pp. 149167.

STEPHENSON, T.A. and STEPHENSON, A. 1972. Life between Tidemarks on Rocky Shores. W.H. Freeman and Company, San Francisco, 425p.

TERZAGHI, K. 1956. Varieties of submarine slope failures. Harvard Soil Mechanics Series, 4lp.

WALTER, H. 1977. Climate. In Ecosystems of the world. Volume 1, Wet coastal ecosystems. Edited by V.J. Chapman. Elsevier Scientific Publishing Co., New York, pp. 61-67.

WOODWARD-CLYDE CONSULTANTS. 1980. Physical Shore-Zone Analysis of the Labrador Coast. Final Report Prepared for Petro-Canada. Various pagination.

Reviewers: J.-C. Dionne

P. McLaren

P.S. Rosen

J.-M. Sempels 